$60^{\circ} \mathrm{C}$ 以下に加温して芫全にとかす $\left(\mathrm{KHCO}_{3}\right.$ 約 $200 \mathrm{~g}$, 多量の具䕀ガスが発生するつ。黒色不溶物を舅別乙, 飽和 重硫酸ソーダ液を加えてブッムを脱色する。無色透明㴓

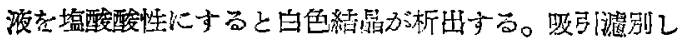
水洗乾燥する。収量 $206 \mathrm{~g}$ (理論》90.8\%)， m.p. $164^{\circ}$ $-166^{\circ} \mathrm{C}_{0}$

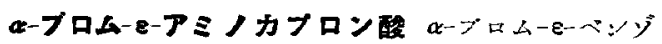
イルテミノカプロン酸 $206 \mathrm{~g}$ に濃塭酸 $1000 \mathrm{cc}$ を加穴,

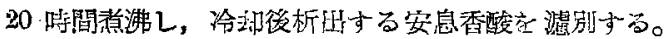

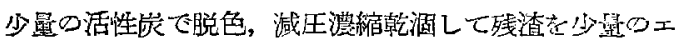

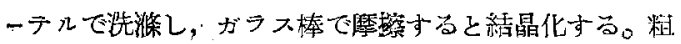

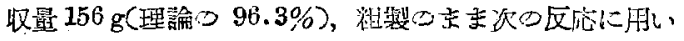
ることがでる。要すれれ゙ノルョールとエーテれで再結 晶でる。収摔 $70.6 \%$, m.p. $105^{\circ} \mathrm{C}$ 。

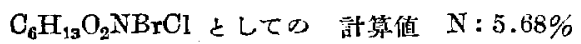
分析徝 $N: 5.53 \%$

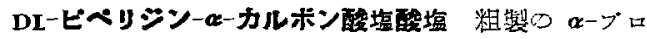
ムーをーアミノカプロソ酸 $156 \mathrm{~g}$ を $120 \mathrm{cc}$ の水にとかし, 等性ソーダ $77 \mathrm{~g}$, 水 $170 \mathrm{cc}$ 心溶液吉加穴, 宝温 $\left(25^{\circ} \mathrm{C}\right)$

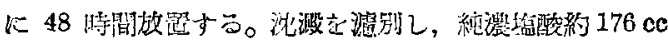

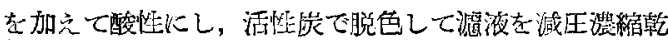

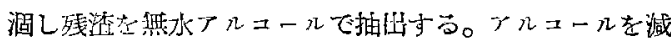

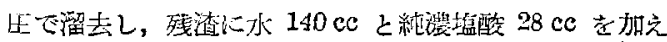

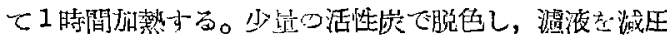

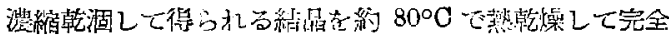

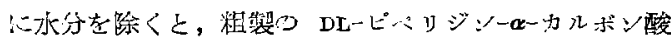

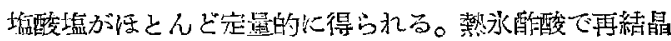

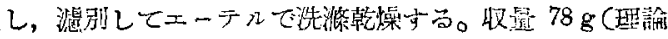
( $74.3 \%$ ), m.p. $259^{\circ} \sim 260^{\circ} \mathrm{C}$ 。

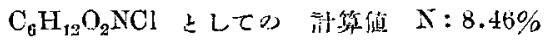
分析砳 $\mathrm{N}: 8.39 \%$

(東北大学理学部化学教室, 倾台书) (昭科 28 年5 月12日受理)

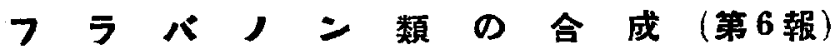 3'ー及び 4'ニトロフラバノンの合成
}

\author{
藤瀬新一郎・藤居良助・前田寿弘・高木邦彥・中村昇太郎
}

dーカンファスれホン酸の存在心然けるオキシカれコン 類よりフラバノン類への閉環に於いて，光学活性フラ バノンを得る不唯合成は数種の例について行われてい、

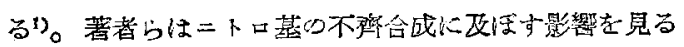

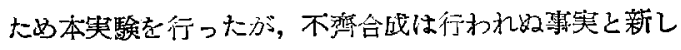
いカルコンとンラパノンを得たので，その結果を㳯告す

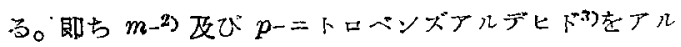

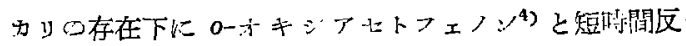

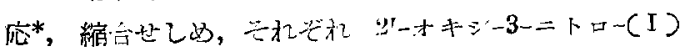

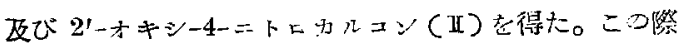

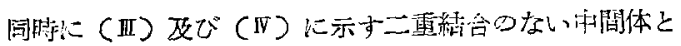

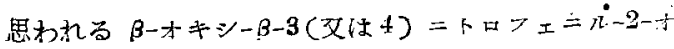
キシプロピオンェノンを生し，このうち(V)は嗑酸と

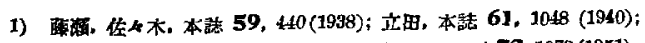

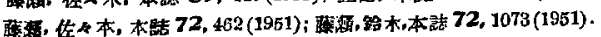

2) W. Davey, J. R. Gwilt, J. Chem. Soc. 1950, 201.

3) Org. Syntheses. 18, 61.

4) J. Meisenheimer, Ann. 539, 83 (1939).
湜せて容易に脱水してカルュン（II）となる。文 (III)

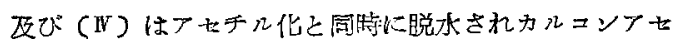
タートになる。これらのカルンン類の酒精溶液に少虽の dーカソファスルホン酸を添加し，封管を用い $130^{\circ} \mathrm{C}$ に

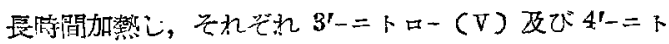

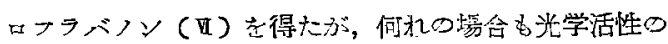

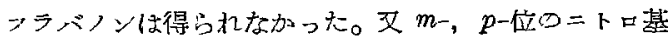
によるフタバノンのの睤環の難易圭比較したが，大きい

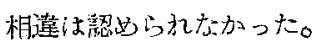

ホキシカルコンに稓けるフミノ基はこの塩基性の為,

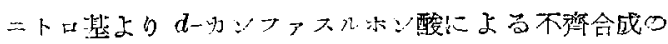
可能性を橧し，又ケミノフラバリン頪は光学活性酸によ

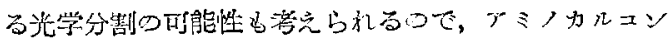

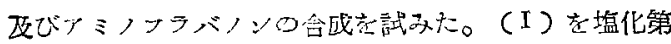

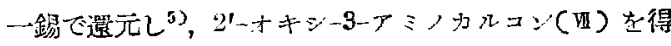

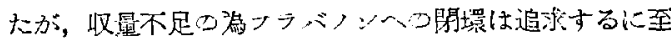

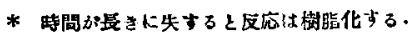

5) J. E. Gowan, T. 8. Wheoler, J. Chem. Soc. 1950, 1925. 


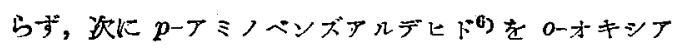
そトフェノンと縮合しようとしたが，原畘回收に終った

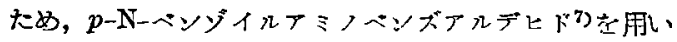
フルカリで縮合せしめ，2'才キシー4-ベンゾイルてミ， カルンン (䜣) を得た。これをlーメンチルアミンの存在 下に封管を用い加熱するる意外にも(

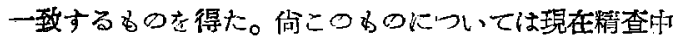
厄名。

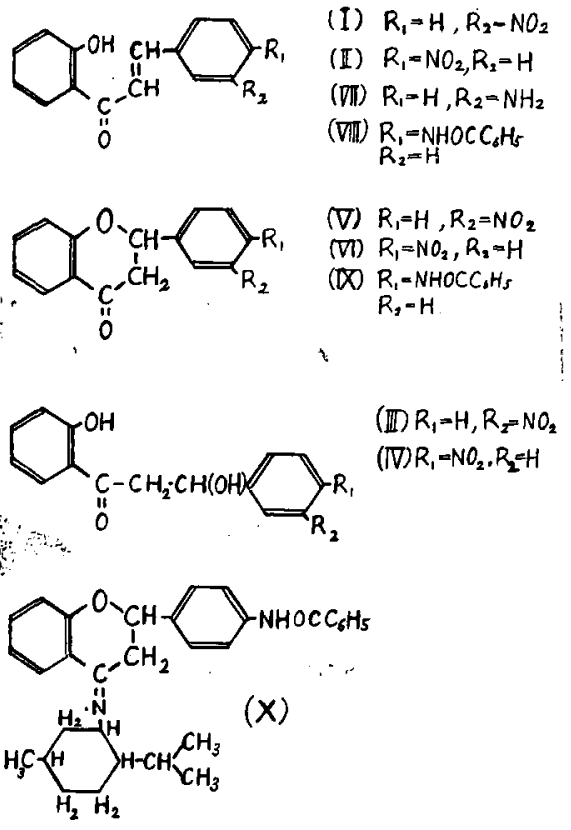

串 験 の 郖

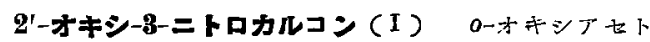
フェノン $4 \mathrm{~g}$ と $m$ ニトロベ:ズフルデヒド $4 \mathrm{~g}$ を $50 \mathrm{cc}$ の酒籍にとかし，湯浴にて $35^{\circ} \mathrm{C}$ に加温しつつ 50\% 部 性ソーダ溶液 $8 \mathrm{~g}$ を加える。溶液が黒褐色になっ公㭙**

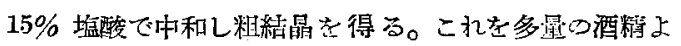

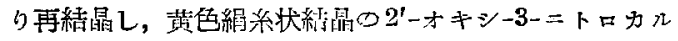
ニソ础点 $164^{\circ} \sim 165^{\circ} \mathrm{C}, 1.3 \mathrm{~g}$ (収湍 $14 \%$ ) と母液より

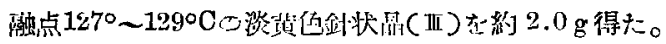

$$
\begin{aligned}
& \text { 2'オキシー3-ニトロカルコンひ分析佔 } \\
& \mathrm{C}_{15} \mathrm{H}_{11} \mathrm{O}_{4} \mathrm{~N} \text { としてい 部算倠 } \mathrm{N} 5.20 \% \\
& \text { 控験低 } \mathrm{N} 5.23 \%
\end{aligned}
$$

9'-アセトオキシ-3-ニトロカルコン（饤） $2.15 \mathrm{~g}$ 世

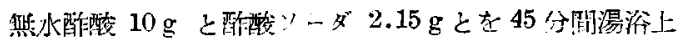

6) P. Friedländer, E. Lenk, Ber. 45, 2087 (1912).

7) P. Pfelffer, Ann. 441, 248 (1925).
に加熱後，水中に注ぎ粗結晶を得る。酒精より再結晶し て淡黃色釬状晶の2'ーナセトすキシー3ーニトロカルニン 融点 $116^{\circ} \sim 117^{\circ} \mathrm{O}, 2 \mathrm{~g}$ を得た。

$$
\begin{aligned}
& \mathrm{C}_{17} \mathrm{H}_{13} \mathrm{O}_{5} \mathrm{~N} \text { としてい 計第值 N } 4.50 \% \\
& \text { 実驗证 N } 4.50 \%
\end{aligned}
$$

メ（I） $0.5 \mathrm{~g}$ 老同椓にアをチル化して同一けアをテ 一ト融点 $115^{\circ} \sim 117^{\circ} \mathrm{C}, 0.47 \mathrm{~g}$ 得た。

3'ーニトロフラパノン (V) 2'オキシー3-ニトロカル エン $1 \mathrm{~g}$ に酒精 $70 \mathrm{cc}$ を加克， $d$-カンファスルホン酸 $0.14 \mathrm{~g}, 0.3 \mathrm{~g}$ 或いは $1 \mathrm{~g}$ をそれぞれ源加し，封管中にて $180^{\circ} \mathrm{C}$ にそれぞれ 45，30 或いい 15 時間加熱して, $3^{\prime}-=$ トロフラバノソの粗紹晶 (カルコンとの混融曲線より推

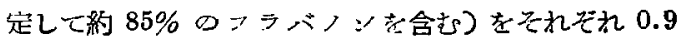
$\sim 0.95 \mathrm{~g}$ を得，木籍より再結晶し，無色釬状晶の $3^{\prime}-二$ トロソラバノン融点 $142^{\circ} \mathrm{C}, 0.5 \mathrm{~g}$ 老得た。旋光度は何 れの場合も認められなかった。

等素分析 $\mathrm{C}_{15} \mathrm{H}_{11} \mathrm{O}_{4} \mathrm{~N}$ としてい 計算值 N $5.20 \%$ 実倹值 N $5.32 \%$

9'オキシー3-アミノカルコン (III) 2'-オキシー3-二

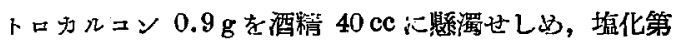
一錫 $4.5 \mathrm{~g}$, 濃塩酸 $30 \mathrm{cc}$ を加穴, 湯浴上に 40 分間煮

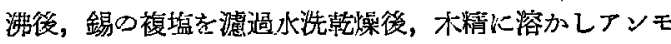
ニア水を加えアルカリ性として無機物を濾別し，母液を

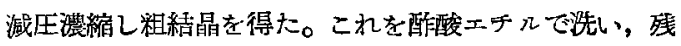
湓を少量の木稍より再結晶し2'ーオキシー3ーアミノカルニ $\checkmark$ 䖲点 $143^{\circ} \sim 144^{\circ} \mathrm{O}, 0.2 \mathrm{~g}$ 在得た。

$$
\begin{aligned}
& \mathrm{C}_{15} \mathrm{H}_{13} \mathrm{O}_{2} \mathrm{~N} \text { としてい 部算值 } \mathrm{N} 5.85 \% \\
& \text { 実験健 N } 5.73 \%
\end{aligned}
$$

2'オキシー4ーニトロルコン (II) $p$-ニトゥベンズ

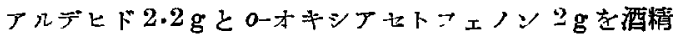
$30 \mathrm{cc}$ に溶解乙 $10 \%$ 苛性ソーダ溶液 $10 \mathrm{cc}$ 老加穴ると, 約 3 分後* 隌赤色になるのので直ちに稀盐酸に中和し粗結 晶を得た。これを酒㮐より再結晶し，少量心黄色釬状晶 の $2^{\prime}$ ーキキジー4ートロカルコン融点 $209^{\circ} \mathrm{C}\left(\mathrm{C}_{15} \mathrm{H}_{11} \mathrm{O}_{4} \mathrm{~N}\right.$ としての計算値 N $5.20 \%$, 実歌值 N $5.20 \%$ )と寿液

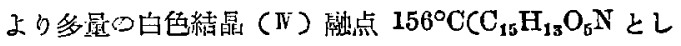
ての計算值 N 4.88\%，浃虽值 N 5.06\%) を得た。

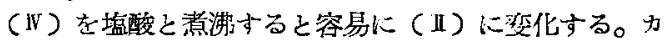
ルュッの総収星は約 $60 \%$ でむる。

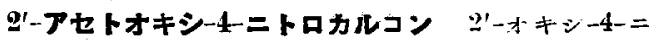

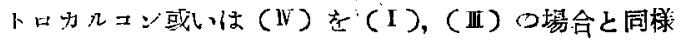

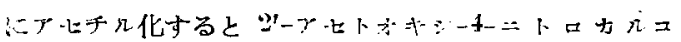
独点 $126^{\circ} \mathrm{C}$ を得る。

* 前桼胜泣照. 


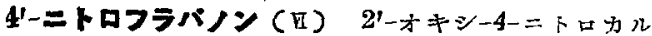

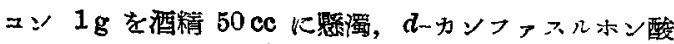

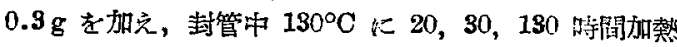

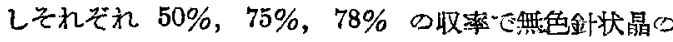
$4^{\prime}$-ニトロフラパノン骶点 $166^{\circ} \sim 167^{\circ} \mathrm{C}$ を得た。何水子旋 光庭は認めら机なかった。

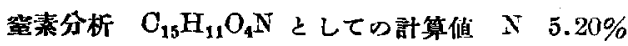

实験估 N $5.18 \%$

3-及び 4-ニトロ-2'-オキシカルコンの開理速度比较 それぞれのカルンン $1 \mathrm{~g}$ を $50 \mathrm{cc}$ の酒精に緐濁し，d カンファスルホン酸 $0.3 \mathrm{~g}$ を加之，封管を用い $130^{\circ} \mathrm{C}$ に 30 帱間加熱し, 3'ーニトロフラバノン 77\% 及び 4'ニトロフラバノン $75 \%$ を得た。

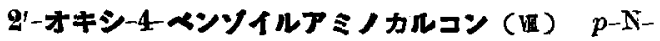

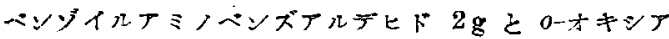
セトフェノシ $1 \mathrm{~g}$ を酒精 $6 \mathrm{cc}$ に溶解して $30 \%$ 苛性ソー

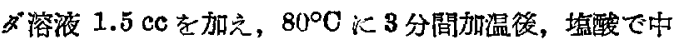
和して得た粗結晶を酒精より再結晶し2゙ーサキシー4ーベ
ゾイルナミノカルコン融点 $208.5^{\circ} \sim 207.0^{\circ} \mathrm{C}, 1.3 \mathrm{~g}$ 得た。

4゙ーペンソイルアミノフラハノン (X) 2' 2'オキシ-4ベンソ์イルアミノカルコン $1 \mathrm{~g}$ に酒精 $40 \mathrm{cc}, d$-カンフ アスルホン酸 $1 \mathrm{~g}$ を加穴封管を用い，1400 に25 時間

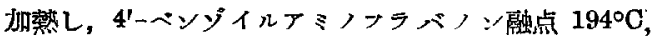
$0.1 \mathrm{~g}$ を得た。旋光度は热めら机なかった。文カルコン $1 \mathrm{~g}$ を酒精 $50 \mathrm{cc}$ に溶解して,l-メンチルてミン告酸塩 $1.5 \mathrm{~g}$ に苛性ソーダ $0.3 \mathrm{~g}$ を加之て得大遊離境基を,その まま加えて封管を朋い $130^{\circ} \mathrm{C}$ に 55 時間加熱し，融点 $160^{\circ} \sim 161^{\circ} \mathrm{C}$ (酒精より再結晶)， $[\alpha]_{\mathrm{b}}^{12}=-78.2^{\circ} \mathrm{C}$ クロ ホんム)のもの $0.54 \mathrm{~g}$ を得た。これは分析值より見て （区）式と思われるが，現在な打精查叶である。

本䂧究費法著者の一人の受けた文部省科学破究䝿によ る。当局に謝箅を棐す。及菱田真三郎氏心助力を受けた 点が多い，分析の一部は岸浪敏䆣が担当されたのて謝意 を表す。

(大阪大学理学部化学教空, 大阪方北区) (昭和 28 年 5 月 18 日受理)

\section{L-グルタ ミンのー新合成法}

赤堀 四 郎・成田耕造

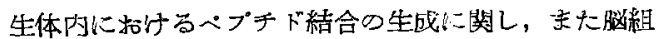
織におけるグルタミン酸代謝に関して，ダルタミンの演 ずる役割が最近注目を浴びる棣になった。しかるに1993

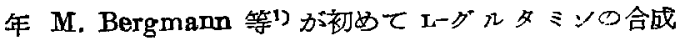
に成功して以来, 種々の合成法が試みられだ〜7けれ

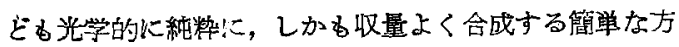
法はなかった。すなわち Bergmann 等は很等の考案に よるカルボペンゾキシ法により,先ずカルボベンゾキシー

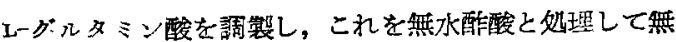
水物となし，この無水物をべンジルフルコールと加欓開 環して

1) M. Bergmann, L. Zervas, L. Bslzmmn, Ber, 66, 1288(1983).

2) N. Liobtenstein, Enzymologia 7, 383 (1999); 9. $185(1941)$.

3) N. Lichtenstein, J. Am. Chem. Soc. 64, 1021 (1942).

4) H. Nienberg, Ber. 68, 2232 (1985).

5) I. G. Farbenindustrie, A. G. B. P. 437,473 (1935); Chem. Abst. 30, 2208 (1936)

6) F. E. King, D. A. A. Kidd, J. Chem. Soc. 1949, 3915

7) F. E. KiDg, B. S. Jackgon, D. A. A. Ridd. fbil.1951, 249
となした後アンモニアを作用させた。かくして得られた カルボヘンソキキシーLーグルタミンテンジルエス・テれを接 触還元して，遊離の 雑な方法を用いた。

グルタミン酸をフルンールを塩化水䒺でエステル化す れば，先ず $\boldsymbol{\gamma}$ 一ンエステルが得られることが明らかに

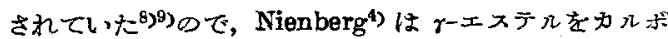
ベンゾキシ誘導体とした後，フンモニアを作用させて直 接カ几ボヘンゾキシーLーグルタミンを合成した。

一方ビロソドンカルボン酸をアンモニアと反店させる とダルタミンが得られると Lichtenstein は報告した2) が，フンモニア我の代りに N-ナルキルナミンを用いれ ばグルタミン酸 $\boldsymbol{\gamma}$-Nーナルキルナミドを与攵るにるかか

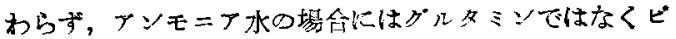

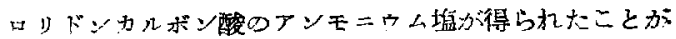

8) E. Abderhsiden, H. Nienberg, Z. physiot. Chem. 219, 165 (1988).

9) M. Bergmann. I. Zervas, 3bir. 221, 51 (1983). 